\section{Gategory}

Metal-Catalyzed Asymmetric Synthesis and Stereoselective Reactions

\section{Key words}

\section{scandium}

1,2-reduction

chiral allylic alcohols

metal borohydrides
P. HE, X. LI, H. ZHENG, W. LI, L. LIN, X. FENG* (SICHUAN UNIVERSITY, CHENGDU,

P. R OF CHINA)

Asymmetric 1,2-Reduction of Enones with Potassium Borohydride Catalyzed by Chiral $N, N^{\prime}$-Dioxide-Scandium(III)

Complexes

Org. Lett. 2012, 14, 5134-5137.

\title{
Scandium-Catalyzed Asymmetric Reduction with Potassium Borohydride
}
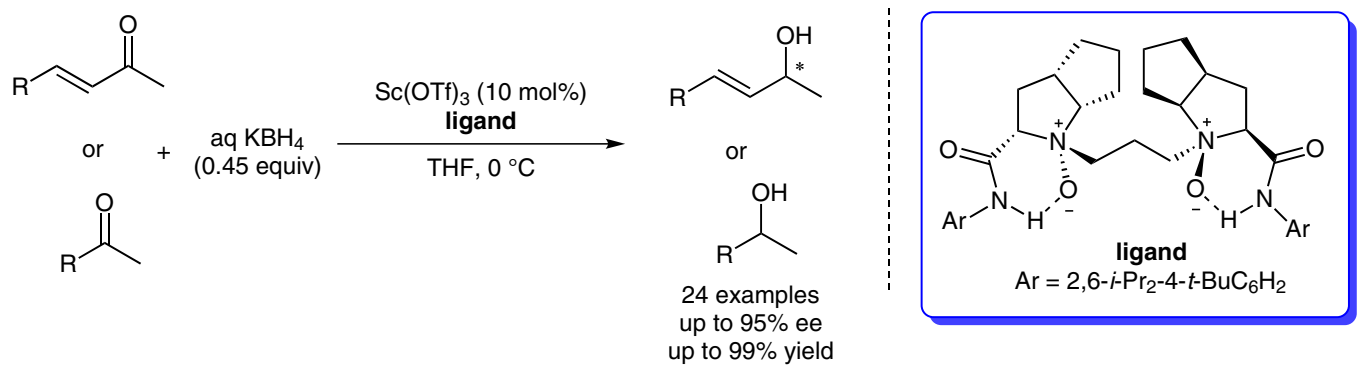

Selected examples:<smiles>C[C@@H](O)/C=C/c1ccccc1</smiles>

$99 \%$ yield, $90 \%$ ee<smiles>CC1=C(/C=C/C(C)O)C(C)(C)CCC1</smiles>

$97 \%$ yield, $90 \%$ ee<smiles>COc1ccccc1/C=C/C(C)=O</smiles>

$99 \%$ yield, $95 \%$ ee<smiles>CC(O)c1ccc2ccccc2c1</smiles>

$97 \%$ yield, $75 \%$ ee<smiles>C[C+](O)C=CC=Cc1ccccc1</smiles>

$99 \%$ yield, $90 \%$ ee<smiles>O[C@H]1CCc2ccccc21</smiles>

$99 \%$ yield, $86 \%$ ee
Significance: As an extension on previous work using chiral $N, N^{\prime}$-dioxide-metal complexes for asymmetric catalysis (see Review), the authors now describe the scandium-catalyzed asymmetric reaction of enones and ketones with $\mathrm{KBH}_{4}$. The resulting chiral alcohols are obtained with good yield and enantioselectivity.

Review: X. Liu, L. Lin, X. Feng Acc. Chem. Res. 2011, 44, 574-587.
Comment: Chiral allylic alcohols are important motifs widely present in natural products and biologically active molecules. The enantioselective reduction of enones is known as the most straightforward access to such motifs. Herein, the first example of catalytic enantioselective reduction of enones and ketones by using $\mathrm{KBH}_{4}$ is reported. The utilization of an aqueous solution of $\mathrm{KBH}_{4}$ was found to be crucial for obtaining high yield and enantioselectivity as the presence of water is believed to benefit proton transfer to accelerate the catalytic cycle. In this case, the reaction was performed in a homogeneous catalyst system. The HRMS spectra experiments indicated that the initial reducing species is $\mathrm{KBH}_{3} \mathrm{OH}$.

SYNFACTS Contributors: Hisashi Yamamoto, Jiajing Tan 